\title{
Forcing and the Event: A Reconstruction of Alain Badiou's Mathematical Philosophy in Being and Event (PhD Abstract, 2012)
}

\author{
BURHANUDDIN BAKI \\ The London Consortium, University of London, UK
}

Published online: 15 October 2016

\begin{abstract}
Alain Badiou's L'Être et L'Événement [Being and Event] (1988) has been enormously influential in reconfiguring the current scene of metaphysical investigations into ontology. But the basic details of its proposed metaontology are still not currently well-understood. My dissertation belongs to a direct attempt at partially filling this gap in the literature. I offer a reconstruction of Badiou's metaontological framework, limiting myself by examining Being and Event only in relation to its specific conditioning by the standard mathematics of set theory up to Paul Cohen's discovery of forcing. Badiou recruits four set-theoretic topics for his metaontology: the formal axiomatic system of ZFC; cardinal and ordinal numbers; Kurt Gödel's the constructible; and Paul Cohen's forcing. For each of these topics, I gather together and clarify the relevant details of the technical mathematics while orienting my explication towards Badiou's interpretation. I will then, more importantly, reconstruct and extend Badiou's conceptual and metaontological meditations in relation to their exact conditioning by the mathematics.
\end{abstract}

